\title{
Alarm Fatigue Questionnaire: Turkish Validity and Reliability Study
}

\author{
Handan ALAN", Hanife TİRYAKİ ŞEN ${ }^{* *}$, Osman BILLGIN ${ }^{* * *}$, Şehrinaz POLAT ${ }^{* * * *}$
}

\begin{abstract}
Aim: The aim of this study was to determine the validity and reliability of the Turkish version of the Alarm Fatigue Questionnaire.

Method: This study used a methodological design and a sample of 140 nurses working in intensive care units in three hospitals in Istanbul, Turkey. Data were collected with the "Personal Information Form" and the "Alarm Fatigue Scale". The data were analyzed at two stages involving adaptation and confirmation. In the adaptation process, four steps including "translation; back-translation; expert opinion; pilot study" were followed.

In the confirmation process, four steps were followed. In the first step, item analyses were carried out. In the second step, to assess the factorability of the correlation matrix, Kaiser-Meyer-Olkin (KMO) sample adequacy test and Bartlett's sphericity test were used. Confirmatory factor analysis (CFA) was used to confirm the original construct. The third step involved testing the internal consistency of the scale. At the final stage, test-retest reliability was assessed by using Pearson's correlation test and paired-samples t-test.

Result: The tool consisted of 13 items and two subscales. Content validity ratings of the scale items were over 0.35 . Fit indices were calculated as: $\chi_{2}^{2} / \mathrm{df}=1.453$, $\mathrm{RMSEA}=0.059$ and $\mathrm{CFI}=0.91$ for the scale. Cronbach's alpha coefficient was 0.71 for scale.

Conclusion: Turkish version of the Alarm Fatigue Questionnaire can be used as a reliable and valid measurement tool for the evaluation of alarm fatigue experienced by nurses working in intensive care units in Turkey.
\end{abstract}

Keywords: Alarm fatigue, intensive care, nursing, psychometric testing, validity and reliability.

\section{Alarm Yorgunluğu Ölçeği: Türkçe Geçerlik ve Güvenirlik Çalışması}

Öz

Amaç: Bu çalışmanın amacı Alarm Yorgunluğu Anketi'nin Türkçe versiyonunun geçerlik ve güvenilirliğini belirlemektir.

Yöntem: Metodolojik tasarımda olan bu çalışmada, İstanbul'daki üç hastanede yoğun bakım ünitelerinde çalışan 140 hemşire örneklemi oluşturmuştur. Veriler "kişisel bilgi formu" ve "Alarm Yorgunluğu Ölçeği" ile toplandı. Verilerin analizinde IBM SPSS Statistics 21 ve AMOS programları kullanıldı. Verilerin analizi

\footnotetext{
Özgün Araştırma Makalesi (Original Research Article)

Geliş / Received: 11.08.2021 \& Kabul / Accepted: 08.12.2021

DOI: https://doi.org/10.38079/igusabder.981451

${ }^{*}$ Ph.D. RN, Dr. Lecturer, Department of Nursing Administration, Florence Nightingale Faculty of Nursing, Istanbul University-Cerrahpasa, Istanbul, Turkey, E-mail: handanalan@istanbul.edu.tr ORCID https://orcid.org/O000-00017414-2288

** Ph.D. RN, Istanbul Health Director, Health Services Presidency, Health Promotion Unit Education Department, Istanbul, Turkey, E-mail: hanifetiryaki@gmail.com ORCID https://orcid.org/oooo-0003-3350-1701

${ }_{* * *}$ Ph.D. Student, Res. Assist., Department of Nursing Administration, Florence Nightingale Faculty of Nursing, Istanbul University-Cerrahpasa, Istanbul, Turkey, E-mail: obilginoo@gmail.com ORCID https://orcid.org/o000-0001-7637-

${ }_{* * * *}^{3071}$ Ph.D. RN, Director, Nursing Services, Istanbul Faculty of Medicine Hospital, Istanbul University, Istanbul, Turkey, E-mail: sehrinaz.polat@gmail.com ORCID https://orcid.org/0000-0002-1884-897X
}

ETHICAL STATEMENT: Before collecting data, permission was received from the corresponding author of the Alarm Fatigue Questionnaire via e-mail. Approval was obtained from the Istanbul University-Cerrahpasa Social Sciences and Humanities Ethics Board of the university (Date: 16.03.2020, number: 44089). 
uyarlama ve doğrulama süreçlerini içeren iki temel aşamada yapıldı. Uyarlama sürecinde "çeviri; geri çeviri; uzman görüşü ve pilot çalışma " olmak üzere dört basamak uygulandı. Doğrulama sürecinde dört basamak takip edildi. İlk adımda madde analizleri yapıldı. İkinci adımda, korelasyon matrisinin faktörlenebilirliğini değerlendirmek için Kaiser Meyer Olkin (KMO) örneklem yeterlik ve Bartlett küresellik testi kullanıldı. Orijinal yapıyı doğrulamak için Doğrulayıcı Faktör Analizi (DFA) kullanıldı. Üçüncü adım, alarm yorgunluğu ölçeğinin iç tutarlılı̆̆ını içermektedir. Son aşamada, test-tekrar test güvenilirliği Pearson korelasyonu ve eşleştirilmiş örneklem $t$ testleri kullanılarak değerlendirilmiştir.

Bulgular: Araç 13 madde ve iki alt ölçekten oluşmaktadır. Ölçek maddelerinin kapsam geçerlilik puanları 0.35 'in üzerindedir. Uyum indeksleri ölçek için $\chi^{2} / \mathrm{df}=1,453$, RMSEA=0,059 ve $\mathrm{CFI}=0,91$ olarak hesaplanmıştır. Ölçek için Cronbach alfa katsayısı 0.71'dir.

Sonuç: Alarm Yorgunluk Anketinin Türkçe versiyonu Türkiye'de yoğun bakım ünitelerinde çalışan hemşirelerin yaşadığı alarm yorgunluğunun değerlendirilmesinde geçerli ve güvenilir bir ölçüm aracı olarak kullanılabilir.

Anahtar Sözcükler: Alarm yorgunluğu, yoğun bakım, hemşirelik, psikometrik test, geçerlilik ve güvenilirlik.

\section{Introduction}

Intensive care units (ICU) are highly complex structures that are designed to treat critical patients who require special care and treatment, and in addition to personnel like doctors, nurses and technicians, contain a set of medical devices with a high volume of sound ${ }^{1}$. While several activities in the intensive care environment are carried out alongside excessive noise, many tasks that are performed by healthcare professionals require high levels of concentration ${ }^{2}$. Noise at ICUs has dramatically increased as a result of complexity, and the effect of noise on patients and personnel has become a significant topic. Accordingly, excessive noise is not just disturbing, but it may also prevent appropriate performance of medical care3 .

The guidelines published by the "World Health Organization" stated that may also influence mental health 4 . Noise may lead to sleep disorders in patients who have had long-term negative effects on hearing ${ }^{1}$. A recent study reported that the mean sound pressure levels were high at an ICU and above the recommended WHO guidelines. It was also determined that alarms rang at a mean number of 170 times per average bed. ${ }^{2}$ Disturbing alarms at ICUs disrupt patient care, and the frequency of false alarms reduces the attention on following alarms 5 .

Nurses working in health institutions, especially in intensive care units, have to manage devices with different alarm threshold values, categories and stimulation types and intervene in alarms. In this case, nurses experience alarm fatigue ${ }^{6}$. Alarm fatigue refers to a nurse getting tired, having sensory overload, getting fed up, not wanting to hear, and after a time, getting desensitized in parallel to burnout as a result of prolonged exposure to high-volume and different alarms7, "The Emergency Care Research Institute (ECRI)" defined alarm fatigue as emotional intensity experienced by healthcare providers when they are excessively exposed to alarm sounds. False alarms were shown as one of the most significant causes of alarm fatigue ${ }^{8}$. False alarms may lead nurses to ignore alarm systems or respond slowly to repeating alarms. Furthermore, false alarms may affect the efficient working of nurses and their performance and distract them 9 .

As a consequence of this, nurses might not only fall inadequate in responding to clinical alarms but also disable or mute alarms without checking. This creates an unsafe environment for patients9-11. "The American Food and Drug Administration (FDA) reported that, from 2002 to 2004, 237 deaths were caused by neglecting clinical alarms" ${ }^{12}$. In the report by "the Joint 
Commission", alarms were shown as the cause of hundreds of deaths, and to improve the safety of alarm systems, "the National Patient Safety Goals" were determined in 2014 ${ }^{13,14}$.

Considering alarm fatigue as a negative phenomenon in patient care and monitoring, there is a need for scales to measure "alarm fatigue in nurses"15. It is seen that scales that are related to the topic are generally those that are used to monitor alarm sounds and measure things like alarm sounds, alarm types, how many times an alarm rings and the effects of alarms on patients ${ }^{16-20}$. For nurses, a scale was developed by Torabizadeh et al. (2017) to measure alarm fatigue ${ }^{15}$. As there is no alarm fatigue scale for nurses in Turkey, this study was aimed to test the psychometric properties of the Nurses' Alarm Fatigue Questionnaire in Turkish.

\section{Material and Methods}

\section{Aim}

This study aimed to test the psychometric properties of the Nurses' Alarm Fatigue Questionnaire for intensive care nurses.

\section{Design}

This is a methodological study with a cross-sectional design.

\section{Location and Sample of the Study}

The data were collected from nurses working at secondary and tertiary intensive care units at healthcare institutions in Istanbul, which is one of the metropolitan provinces of Turkey.

The sample size was determined as 5-10 times the number of items in the scale, based on the number of scale items suggested in the literature ${ }^{21-24}$. Since the scale has 13 items, the sample was planned to include at least 65 nurses. It was aimed to reach 10 times the number of items in the Alarm Fatigue Questionnaire (130). The sample consisted of 140 nurses who volunteered to participate who were employed at a hospital under the Ministry of Health, a private hospital and a university hospital. The study was conducted in accordance with the "Principles of the Declaration of Helsinki”.

\section{Data Collection Instrument}

The data were collected between 1-15 June 2020 by sharing the online questionnaire form prepared by the researchers on WhatsApp groups by supervisor nurses. The online data collection instrument consisted of three pages. On the first page, the nurses were informed about the objective, scope and ethical aspects of the study. Those who agreed to provide data were able to move onto the other pages of the data collection instrument by checking the approval box. The second page included a personal information form, and the third page included the Alarm Fatigue Questionnaire developed by Torabizadeh et al. (2017) ${ }^{15}$.

Personal Information Form: The form included 11 questions on the personal information of the nurses such as age, gender, marital status and educational level and their occupational information such as the institution of work, professional and intensive care experience, type of intensive care, way of working and status of having an intensive care certificate. The questions were prepared by the researchers in line with the literature.

Alarm Fatigue Questionnaire: The questionnaire was developed by Torabizadeh et al. (2017) to determine the psychological pressure felt due to alarms by nurses working at ICUs ${ }^{15}$. It is a 5 -point Likert-type scale (o: never - 4: always). The possible score range in the scale is 8-44. Higher scores in the scale indicate higher levels of alarm fatigue and affected performance. 


\section{Data Analysis}

The data were analyzed by the researchers using SPSS 25.0. In addition, the AMOS 22.0 was used for confirmatory factor analysis. The data were analyzed using "Content Validity Index, Dependent Samples t-test, Pearson Correlation Analysis, Item Analysis and Confirmatory Factor Analysis". The statistical results were considered significant at $95 \%$ confidence interval and $\mathrm{p}$ $<0.05$.

The data were analyzed at two stages involving adaptation (translation; back-translation; expert opinion; pilot study) and confirmation ("item analyses, Kaiser-Meyer-Olkin-KMO, Bartlett's sphericity test, Confirmatory factor analysis-CFA, the internal consistency, test-retest, Pearson's correlation test and paired-samples t-test") ${ }^{25}$. Figure 1 shows all these steps.

Figure 1. Study process

\section{Study Process}
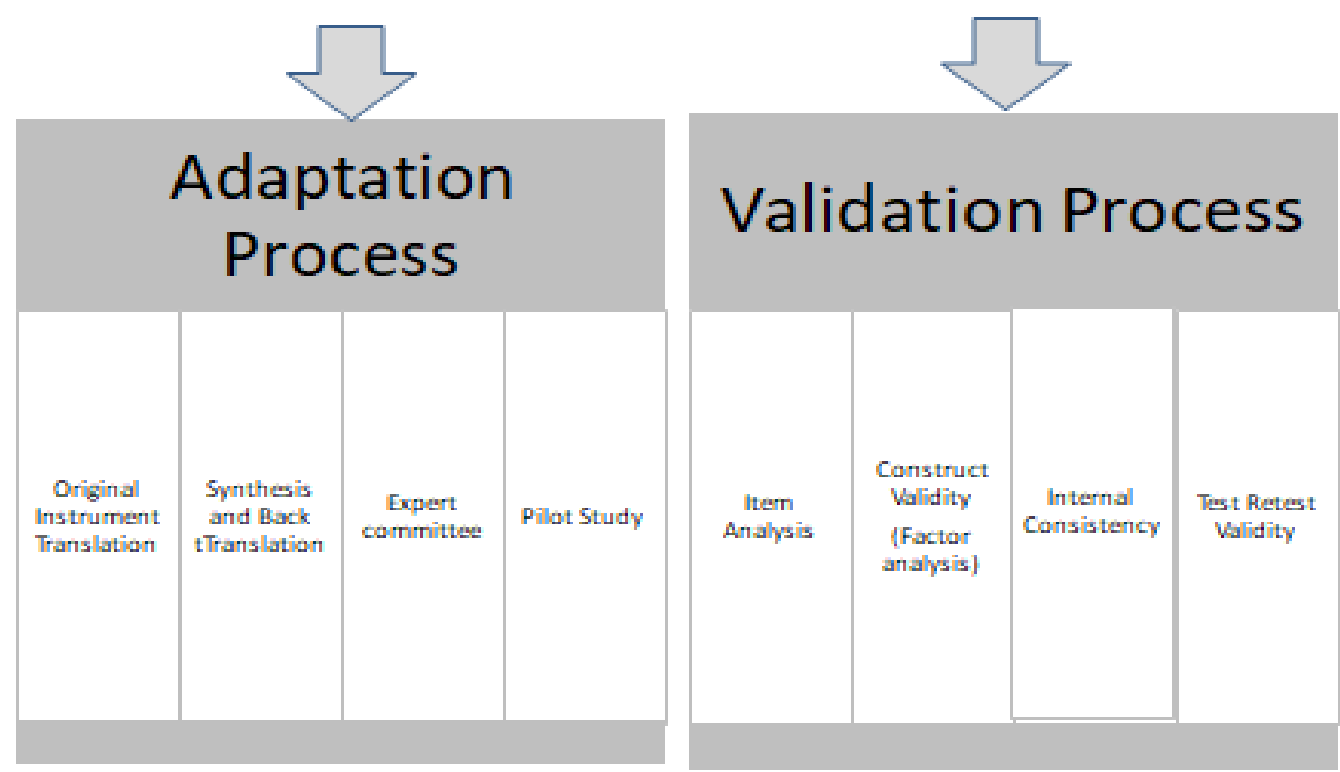

\section{Study Ethics}

Before collecting data, permission was received from the corresponding author of the Alarm Fatigue Questionnaire via e-mail. Approval was obtained from the Istanbul UniversityCerrahpasa Social Sciences and Humanities Ethics Board of the university (date: 16.03.2020, number: 44089).

Information was provided on the objective and process of the study for the nurses on the first page of the online form. The nurses who agreed to participate could reach the data collection form after marking the informed consent form here.

\section{Results}

Among the nurses who participated in the study, most were female (83.6\%), married (60.7\%) and had undergraduate degrees (55.7\%), were working at the hospitals of the Ministry of Health 
(44.3\%), at tertiary ICUs (78.6\%), at adult ICUs (64.3\%), without a certificate (55\%) and in the form of shifts (84.3\%). Most of the nurses were at the ages of 21-56 (mean=29.91 \pm 7.29 ), while their professional experience was in the range of $1-38$ years (mean=8.38 \pm 7.64 ), and their intensive care experience was in the range of $1-38$ years (mean $=5.97 \pm 6.42$ ).

\section{Adaptation Process}

At the beginning of this process, the scale was translated from English to Turkish by two independent individuals who had native-level Turkish and English knowledge. The text translated into Turkish was turned into a single text by two academician nurses who spoke English. The researchers discussed over the Turkish forms, and the necessary revisions were made in terms of meaning and grammar. After the Turkish translation of the scale items, the items were submitted for the opinions of individuals who were experts in the field of nursing and experienced regarding scale development and adaptation. At the third stage, the "Davis technique" was used for the content validity of the scale ${ }^{26,27}$. Based on the opinions collected from 10 experts who assessed the items in line with the "Davis technique", the content validity indices of the items were found to be in the range of .80-1.oo. Finally, a pilot study was carried out with 22 nurses working at an intensive care unit who were excluded from the main sample of the study.

\section{Confirmation Process}

Item analyses: Upon determining that the goodness of fit indices did not confirm the original scale construct, item analysis was conducted to determine the items that showed a low correlation with the entire scale. As a result of the item analysis, it was observed that the item-total correlations of all items except for one were over 0.30. Item 9, which had an item-total correlation coefficient of 0.09, was removed from the scale. In the repeated item analysis, it was seen that the remaining 12 items had a corrected item-total correlation coefficient of .35-.85, and the analyses continued with these 12 items.

Table 1. Goodness of fit values of the structural model of the alarm fatigue questionnaire

\begin{tabular}{|c|c|c|}
\hline & Structural Model Values & Recommended Values \\
\hline$x^{2} / \mathrm{df}$ & 1,453 & $\leq 3$ \\
\hline RMSEA & 0,059 & $\leq 0,08$ \\
\hline GFI & 0,915 & $\geq 0,80$ \\
\hline CFI & 0,911 & $\geq 0,80$ \\
\hline SRMR & 0,080 & $\leq 0,10$ \\
\hline & \multicolumn{2}{|c|}{ X2: 72.673, df:5o, p:o,o20 } \\
\hline
\end{tabular}

"df = degrees of freedom, RMSEA = Root mean square error of approximation, GFI $=$ Goodness of fit index, $\mathrm{CFI}=$ Comparative fit index, IFI $=$ incremental fit index"

Construct validity: "The KMO and Bartlett's test of sphericity" were used to assess whether the sample was adequate and whether the factor correlation matrix was suitable for factor analysis. The KMO value was .675; the "Bartlett's test" result was $\chi^{2}=321.667$ and statistically highly significant $(\mathrm{p}<0.001)$. The factor loads of the two-factor scale were in the range of .30-.90. The goodness of fit indices was calculated as $\chi^{2}=131.27 ; \mathrm{df}=52 ; \mathrm{RMSEA}=.059 ; \mathrm{GFI}=.92$; AGFI $=.87 ; \mathrm{CFI}=.91 ; \mathrm{IFI}=.92$ (Table 1$)$. 
Figure 2. Construct validity

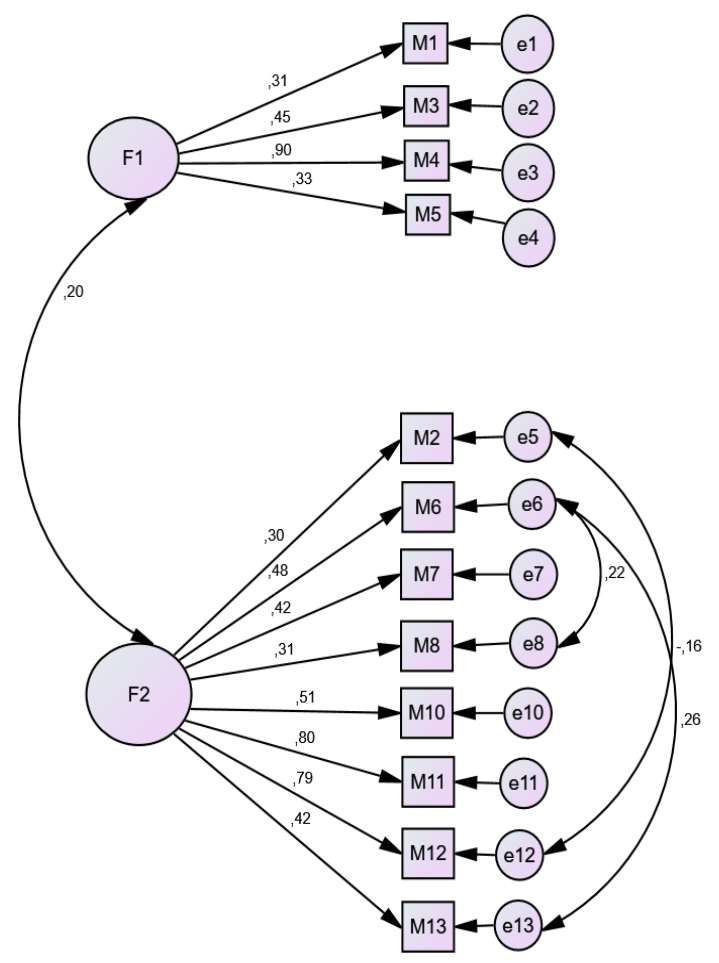

It was determined that the factor loads of the scale items were above the previously determined limit of .30, and the goodness of fit indices was on normal levels (Figure 2).

Table 2. Descriptive and psychometric properties of alarm fatigue questionnaire

\begin{tabular}{|l|l|l|l|l|l|}
\hline & ITEMS & $\alpha$ & Min-Max & M & SD \\
\hline $\begin{array}{l}\text { Alarm Fatigue } \\
\text { Questionnaire }\end{array}$ & $1,2,3,4,5,6,7,8,10,11,12,13$ & .71 & $6-38$ & 23.55 & 6.33 \\
\hline F1 & $1,3,4,5$ & .63 & $4-16$ & 11.79 & 2.55 \\
\hline F2 & $2,6,7,8,10,11,12,13$ & .74 & $1-24$ & 11.76 & 5.40 \\
\hline
\end{tabular}

"M= Mean, $\mathrm{SD}=$ standard deviation, Min = minimum, Max = maximum"

Internal consistency: To determine the internal consistency of the measurements obtained from the scale, "Cronbach's alpha analysis", which is prevalently used for especially Likert-type scales, was carried out. "The Cronbach's alpha" values were .69 in the total scale and, .63 and .71 in the subscales (Table2). 
Table 3. Test-retest reliability

\begin{tabular}{|c|c|c|c|}
\hline & & $\mathbf{M} \pm \mathbf{S D}$ & $\begin{array}{l}\mathbf{t} / \mathbf{p} \\
\mathbf{r} / \mathbf{p}\end{array}$ \\
\hline \multirow{2}{*}{$\begin{array}{l}\text { Alarm Fatigue } \\
\text { Questionnaire }\end{array}$} & 1 st & $27.58 \pm 4.32$ & $\begin{array}{l}\mathrm{t}=.230 \\
\mathrm{p}=.456\end{array}$ \\
\hline & 2nd & $27.82 \pm 4.55$ & $\mathrm{r}=.726, \mathrm{p}<.001^{* *}$ \\
\hline \multirow[t]{2}{*}{ F1 } & $1 \mathrm{st}$ & $12.37 \pm 1.60$ & $\begin{array}{l}t=.966 \\
p=.158\end{array}$ \\
\hline & 2nd & $11.89 \pm 1.64$ & $\mathrm{r}=.864, \mathrm{p}<.001^{* *}$ \\
\hline \multirow{2}{*}{ F2 } & 1st & $14.39 \pm 4.68$ & $\mathrm{t}=1.215, \mathrm{p}=.533$ \\
\hline & 2nd & $14.13 \pm 4.66$ & $\mathrm{r}=.775, \mathrm{p}=.001^{*}$ \\
\hline
\end{tabular}

Test-retest reliability: The 13-item Alarm Fatigue Questionnaire was applied two times on 25 nurses with a two-week interval. The relationship between the two measurements was analyzed by paired-samples t-test and Pearson's correlation analysis. As a result of the analysis, the correlation coefficient for the entire scale was .726 $(\mathrm{p}<.001)$. The paired-samples t-test results $(\mathrm{t}$ $=0.230, p=.726$ ) were not found significant (Table 3 ).

\section{Discussion}

At the beginning of the study, alarm fatigue scales were investigated by reviewing the literature. As a result, it was determined that there was no instrument for assessing the alarm fatigue of nurses working in Turkey. The Alarm Fatigue Questionnaire developed by Torabizadeh et al. (2017) was assessed to be the most suitable instrument. To achieve linguistic validity, methods recommended by "the World Health Organization" and the "International Test Commission" for adaptation of instruments developed in different languages were followed ${ }^{23,24}$. Content validity analysis was conducted ${ }^{25} .10$ experts who were working at the ICU and conducting scale development and adaptation studies assessed the items. As a result of the pilot study, the final form of the scale was prepared.

In the confirmation process, the data of the questionnaires filled out by 140 nurses were analyzed. As a result of "the item analysis" conducted at the first stage, one item that was determined to have a correlation value lower than those accepted in the literature (0.30-0.40) was removed from the scale. At the end of the CFA carried out to confirm the consistency of the sample with the construct of "the original scale", it was determined that all items had factor loads of .35 or higher. These values were over the value accepted as the lower limit for factor loads as $0.30^{21,25}$. In "itemtotal correlation analysis" that explains the relationship between the score of each item in a scale and the score of the total scale, positive and high correlation values show that the items exemplify similar behaviors, and "the internal consistency" is high"28. As a low item-total correlation value from the analysis also lowers the reliability of the scale, the relationship between these variables is expected to be not negative or low ${ }^{21}$. Bayer (2018) stated that correlation values of under .30 show that the items are inadequate, but those with a correlation value of .20-.30 could be included in the scale if considered necessary, while items with a correlation value of higher than 40 show that these items have a good discrimination power ${ }^{28}$. To increase the reliability of the scale, in this 
study, an item with a low discrimination power was removed from the scale by elimination of it due to its lower item-total correlation value than .30.

There is no general consensus regarding values that need to be reported in "confirmatory factor analysis" ${ }^{26}$. In this study, the most frequently utilized fit indices of " $\chi^{2}$ / df, RMSEA, GFI, NNFI, CFI and IFI" were calculated and reported. The construct of the scale had generally acceptable goodness of fit 29 .

The internal consistency coefficient of the Alarm Fatigue Questionnaire was .71. For an internal consistency measurement to be reliable, the alpha coefficient needs to be at least in the range of $0.60-0.70^{21}$. The results of this study were highly reliable.

The Fatigue Questionnaire were tested "against time-invariance". The scale was applied again on 25 intensive care nurses. As a result of "paired-samples analysis", it was determined that there was no significant difference between the measurement results, and the results were positively and significantly related. These results proved the time-invariance of the results obtained from the Alarm Fatigue Questionnaire.

\section{Conclusion}

In this study where the validity and reliability of the Turkish form of the Alarm Fatigue Questionnaire were tested in a sample of nurses, it was determined that the goodness of fit indices of the 13-item original construct of the scale did not confirm the original scale construct. Accordingly, as recommended in the literature, one item showing a low correlation with the entirety of the scale was eliminated. In the confirmatory factor analysis that was conducted again to assess the fit of the discovered construct, by applying some modification recommendations, acceptable fit values were obtained. The final form of the 12-item Turkish version of the scale was determined to satisfy validity and reliability criteria to an acceptable extent.

As this is a newly adapted scale, it may be recommended to discover its constructs by re-testing in different samples or to use it to assess its currently reported construct.

\section{REFERENCES}

1. Konkani A, Oakley B. Noise in hospital intensive care unit a critical review of a critical topic. Journal of critical care. 2012; 27(5):522-e1. https://doi.org/10.1016/j.jcrc.2011.09.003.

2. Vreman J, Van Loon LM, Van Den Biggelaar W, Van Der Hoeven JG, Lemson J, Van Den Boogaard M. Contribution of alarm noise to average sound pressure levels in the ICU: An observational cross-sectional study. Intensive and Critical Care Nursing, 2020;102901. https://doi.org/10.1016/j.iccn.2020.102901.

3. Despins LA. Factors influencing when intensive care unit nurses go to the bedside to investigate patient related alarms: A descriptive qualitative study. Intensive and Critical Care Nursing. 2017; 43:101-107. https://doi.org/10.1016/j.iccn.2017.04.003.

4. Clark C, Paunovic K. WHO environmental noise guidelines for the european region: A systematic review on environmental noise and cognition. International journal of environmental research and public health. 2018;15(2):285. https://doi.org/10.3390/ijerph15020285.

5. Casey S, Avalos G, Dowling M. Critical care nurses' knowledge of alarm fatigue and practices towards alarms: A multicentre study. Intensive and Critical Care Nursing. 2018;48:36-41. https://doi.org/10.1016/j.iccn.2018.05.004. 
6. Ergezen FD, Kol E. Nurses' responses to monitor alarms in an intensive care unit: An observational study. Intensive and Critical Care Nursing . 2020;102845. https://doi.org/10.1016/j.iccn.2020.102845.

7. Ergezen FD, Kol E. Alarm fatigue in critical care nurses and it's management. Yoğun Bakrm Hemşireliği Dergisi. 2019;23(1):43-49.

8. Christensen M, Dodds A, Sauer J, Watts N. Alarm setting for the critically ill patient: A descriptive pilot survey of nurses' perceptions of current practice in an Australian regional critical care unit. Intensive and Critical Care Nursing. 2014;30(4):204-210. https://doi.org/10.1016/j.iccn.2014.02.003.

9. Sendelbach S. Alarm fatigue. Nurs Clin North Am. 2012;47(3):375-82. https://doi.org/10.1016/j.cnur.2012.05.009.

10. Lewandowska K, Weisbrot M, Cieloszyk A, Mędrzycka-Dąbrowska W, Krupa S, Ozga D. Impact of Alarm Fatigue on the work of nurses in an intensive care environment-A systematic review. International Journal of Environmental Research and Public Health. 2020;17(22):8409. https://doi.org/10.3390/ijerph17228409.

11. Paine CW, Goel VV, Ely E, Stave CD, Stemler S, Zander M, Bonafide CP. Systematic review of physiologic monitor alarm characteristics and pragmatic interventions to reduce alarm frequency. Journal of Hospital Medicine. 2016;11(2):136-144. https://doi.org/10.1002/jhm.2520.

12. Hannibal GB. Monitor alarms and alarm fatigue. AACN Adv Crit Care. 2011;22(4):418-20. https://doi.org/10.4037/NCI.obo13e318232ed55.

13. Nix M. Combating alarm fatigue. Am J Nurs. 2015;115(2):16. doi: 10.1097/01.NAJ.0000460671.80285.6b.

14. The Joint Commission. National patient safety goals: 2014 national patient safety goals. Chicago. 2013. http://www.jointcommission.org/standards information/npsgs.aspx.

15. Torabizadeh C, Yousefinya A, Zand F, Rakhshan M, Fararooei M. A nurses' alarm fatigue questionnaire: Development and psychometric properties. Journal of Clinical Monitoring and Computing. 2017;31(6):1305-1312. https://doi.org/10.1007/s10877-016-9958-x.

16. Bi J, Yin X, Li H, Gao R, et al. Effects of monitor alarm management training on nurses' alarm fatigue: A randomised controlled trial. Journal of Clinical Nursing. 2020;29(2122):4203-4216. https://doi.org/10.1111/jocn.15452.

17. Graham KC, Cvach M. Monitor alarm fatigue: Standardizing use of physiological monitors and decreasing nuisance alarms. American Journal of Critical Care. 2010;19(1):28-34. https://doi.org/10.4037/ajcc2010651.

18. Baillargeon E. Alarm fatigue: A Risk Assessment. [master's thesis]. US: Rhode Island College; 2013.

19. Funk M, Clark JT, Bauld TJ, Ott JC, Coss P. Attitudes and practices related to clinical alarms. Am J Crit Care. 2014;23(3):9-18. https://doi.org/10.4037/ajcc2014315.

20. Cho OM, Kim H, Lee YW, Cho I. Clinical alarms in intensive care units: Perceived obstacles in alarm management and alarm fatigue in nurses. Healthc Inform Res. 2016;22(1):46-53 https://doi.org/10.4258/hir.2016.22.1.46.

21. Tavşancll E. Measuring Attitudes and data Analysis with SPSS. 5th edition. Ankara: Nobel Akademik Yayıncılık Eğitim Danışmanlık Tic. Ltd.Şti; 2014.

22. Capik C, Gozum S, Aksayan S. Intercultural scale adaptation stages, language and culture adaptation: updated guideline. Florence Nightingale J.Nurs. 2018;26:199-210. Doi: 10.26650/fnjn397481.

23. International Test Commission. The ITC guidelines for translating and adapting tests. International Test Commission. 
https://www.intestcom.org/files/guideline_test_adaptation_2ed.pdf. Published 2017. Accessed Date 18 July 2020.

24. World Health Organization. Process of translation and adaptation of instruments. https://www.who.int/substance_abuse/research_tools/translation/en/. Published 2019. Accessed 17 July 2020.

25. Polit DF, Beck CT. Nursing Research: Principles and Methods. Philadelphia: Lippincott Williams \&Wilkins; 2012.

26. Simsek ÖF. Introduction to Structural Equation Modeling, Fundamental Principles and LISREL Applications. Ankara: Ekinoks Pres; 2007.

27. Davis LL. Instrument review: Getting the most from a panel of experts. Applied Nursing Research. 1992;5(4):194-197. https://doi.org/10.1016/So897-1897(05)80008-4.

28. Bayer N, Baykal Ü. Improving Quality Perception Scale of Health Workers. Journal of Health and Nursing Management. 2018;5(2):86-99. doi:10.5222/SHYD.2018.086.

29. Kline P. An Easy Guide to Factor Analysis. 1. ed. New York: Taylor \& Francis Group; 1994. 